\title{
Effect of mulching dates modified for nature conservation on the yield and nitrogen fixation of green manure lucerne crops
}

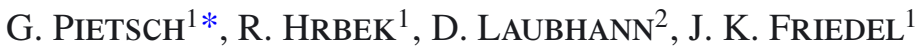 \\ ${ }^{1}$ Division of Organic Farming, Department of Sustainable Agricultural Systems, University of Natural Resources and Applied Life Sciences, Vienna \\ ${ }^{2}$ Institute of Botany, Department of Integrative Biology and Biodiversity Research, University of Natural Resources and Applied Life Sciences, Vienna, Gregor \\ Mendel Strasse 33, 1180 Vienna, Austria
}

(Accepted 3 October 2008)

\begin{abstract}
Organically managed fields are highly attractive for wild animals of open agricultural landscapes because of a high percentage of green covered fields; for example, by green manures, catch crops and underseeds. Forage legumes are the main source of nitrogen in organic farming. Forage legumes are also important habitats for wild animals. The main ecological disadvantage is frequent mowing of forage crops. Increasing the time without disturbance in favour of wild animals may also decrease crop productivity and increase weed pressure. Here, we studied the effect of modified mulching dates on yield, nitrogen fixation and weed colonisation of lucerne green manure under pannonian site conditions during two vegetation periods in Eastern Austria. We compared a natural treatment, where the first mulching took place two weeks earlier and the second mulching two weeks later than in a conventional treatment with the latter. While in the first year the shoot dry-matter yield $\left(-1.5 \mathrm{t} \mathrm{ha}^{-1}\right)$, nitrogen yield and the amount of fixed nitrogen $\left(-44 \mathrm{~kg} \mathrm{~N} \mathrm{ha}^{-1}\right)$ in lucerne were significantly lower in the natural than in the conventional treatment at the first cut, no differences could be detected in the second year. The seasonal amount of nitrogen fixation as well as the percentage of $\mathrm{N}$ derived from the atmosphere $\left(\mathrm{N}_{\mathrm{dfa}}\right)$ at both cuts did not differ between the treatments. The natural treatment also had no disadvantageous effects on weed coverage. Our results show that prolonging the period without disturbance in lucerne crops had no adverse agronomic effects with only one exception: the 14-day shorter development period in the natural treatment at the first cut decreased shoot yield and nitrogen fixation compared with the conventional treatment in the first year, when weather conditions were humid before the first cut and dry afterwards. We therefore recommend shifting mulching dates and prolonging cutting intervals in lucerne on organic farms under pannonian site conditions in favour of wild animals.
\end{abstract}

Lucerne / nitrogen fixation / nature conservation / mulching regime / wild animals / weed pressure

\section{INTRODUCTION}

Forage legumes are the main source of nitrogen for nonlegumes in crop rotations of organic farming. The yield and product quality of following cereals depend on the $\mathrm{N}$ (nitrogen) gain by biological nitrogen fixation of the forage legumes (Wivstad et al., 1996). Lucerne (Medicago sativa L.) is the most important perennial forage legume in the crop rotation used in organic farming systems under warm and dry climatic conditions like in eastern Austria. In stockless organic farming, mulched lucerne crops, when the green manure is left on the soil surface ("mulching"), can symbiotically fix 159$230 \mathrm{~kg} \mathrm{~N} \mathrm{ha}^{-1}$ per year (Loges et al., 1999; Pietsch et al., 2007). Crop management aims at optimising the $\mathrm{N}$ gain by biological nitrogen fixation and the $\mathrm{N}$ delivery to following crops (de Kruijff et al., 2008).

\footnotetext{
* Corresponding author: gabriele.pietsch@boku.ac.at
}

Organic farming has less negative impacts on the environment than conventional farming (Stolze et al., 2000; El-Hage Scialabba and Hattam, 2002) and contributes to species richness by supporting and integrating biodiversity into and alongside the cultivated land (van Elsen, 2000; Hole et al., 2005; Petersen et al., 2006). Organically cultivated land is highly attractive for wild animals of the open agriculture landscape because a higher percentage of the fields is green covered by fallows, catch crops and underseeds than on conventional farms. Forage legumes comprise up to $30 \%$ of the organic crop rotation and therefore play a crucial role in nature conservation (Stein-Bachinger et al., 2005).

Especially lucerne provides excellent habitats due to its nesting cover, abundant insects, perennial growth pattern and feeding opportunities for many species, among them songbirds, swallows, quails, migratory birds, rabbits and deer. Stein-Bachinger and Fuchs (2004) confirmed the importance of forage production (legume and legume-grass mixtures) for 
ground-breeding birds compared with other crops. The main disadvantage for wild animal species is frequent mowing of lucerne, which often destroys nests and eggs and disturbs incubating hens of ground-breeding birds (Berdahl et al., 2004; Putnam et al., 2001).

The Marchfeld region in eastern Austria is one of the most important regions of intensive crop production in the country. It is characterised by large cultivation units and a small share of landscape elements like hedgerows, field margins or fallows. The intensive agriculture here causes many environmental problems, especially groundwater pollution by nitrate and pesticide inputs, along with declining soil fertility and ecosystem diversity (Hadatsch et al., 2000). Only a few farms follow organic farming guidelines in this region. The first seasonal cut of perennial lucerne is typically the most productive, often providing $40-50 \%$ or more of the total forage yield per season (Latheef et al., 1988). Usually, the first cut of lucerne crops sown in the preceding year takes place in late May to mid-June in the Marchfeld region. At this time, young ground-breeding birds are not fully fledged and young hares are in the fields (Stein-Bachinger and Fuchs, 2004). A single mulching event during the sensitive reproduction periods of the key species (e.g. brown hare or skylark) is detrimental (Kelemen-Finan and Frühauf, 2005). High mortality rates and decreased reproductive success of ground game (e.g. brown hare) and groundbreeding birds were observed in the Marchfeld region through the common practice of chaffing and mulching lucerne crops between late May and mid-June (Kelemen et al., 2003). A delayed first cut and prolonging the mulching intervals of forage legumes across the breeding season - a minimum interval of seven weeks between the first and second cuts - improve the reproductive success of ground-breeding birds, e.g. skylarks (Kelemen-Finan and Frühauf, 2005; Stein-Bachinger et al., 2005). In the northern Great Plains (USA), for example, nesting success of waterfowl, pheasants and other upland nesting birds was greatly improved when haying was delayed from June to July or later (Berdahl et al., 2004). Other beneficial effects on reproductive success of wild animals can be obtained by increasing the cutting height, using special harvesting techniques, and including structural features such as unmown strips (Stein-Bachinger et al., 2005).

The dry-matter (DM) yield of lucerne increases with advancing maturity, but the forage quality, e.g. crude protein, is reduced (Frame et al., 1998; Lloveras et al., 1998; Sheaffer et al., 2000; Stein-Bachinger and Fuchs, 2004; Veronesi et al., 1981). The question remains whether dry-matter and $\mathrm{N}$ yield as well as nitrogen fixation capacity of lucerne crops are also influenced by a mulching date adapted to a nature conservation management in the dry Marchfeld region. This may also affect their pre-crop value in organic crop rotations. The present study was carried out in the frame of a research project (Kelemen-Finan and Frühauf, 2005) analysing the effects of agriculture on key species (brown hare, grey partridge, sky lark and quail) of open agricultural landscapes in the Marchfeld region. Despite their differing habitat requirements, these four key species showed a positive effect of variously structured and managed fallow habitats and a high affinity to lucerne. Our objective was to study the agronomic consequences of shift- ing the mulching date of lucerne crops with respect to nature conservation. We tested if lucerne crops under two differing mulching regimes - optimised with respect to nature conservation with a prolonged period without disturbance between the first and second cuts versus managed according to conventional practice - (i) produce the same amount of above- and below-ground dry matter, (ii) have the same $\mathrm{N}$ content and $\mathrm{N}$ yield, (iii) fix the same amount of atmospheric nitrogen and (iv) have the same effect on weed coverage.

\section{MATERIALS AND METHODS}

\subsection{Trial sites and experimental procedure}

The experiment was conducted on an organically managed field of the University of Natural Resources and Applied Life Sciences Vienna, Austria. The trial site is located in the Marchfeld area, approx. $5 \mathrm{~km}$ east of Vienna in Raasdorf $\left(48^{\circ} 14^{\prime} \mathrm{N}\right.$, $\left.16^{\circ} 35^{\prime} \mathrm{E}\right)$ at an altitude of $150-160 \mathrm{~m}$ above sea level. The Marchfeld climate is characterised by hot, dry summers with little dew, and cold winters with little snow. The long-term average (1971-2000) annual precipitation is $520 \mathrm{~mm}$; the mean annual temperature is $9.8^{\circ} \mathrm{C}$. The soil is a Calcaric Phaeozem (WRB, 1998) from Loess with a silty loam texture, organic carbon contents of $2.2 \%$ in the $\mathrm{A}_{\mathrm{p}}$ horizon, and a $\mathrm{pH}$ value of 7.6 measured in a $0.01 \mathrm{M} \mathrm{CaCl}_{2}$ suspension at a soil-tosolution ratio of $1: 2.5$.

Farm management is without livestock, so no organic manures were applied and all plant material remained on the field, corresponding to a green manure system. Crop rotation during the experimental period was summer barley / catch crop (2003) - lucerne (2004, first year of production) - lucerne (2005, second year of production). In 2004, lucerne, cv. Sitel (seeding density $25 \mathrm{~kg} \mathrm{ha}^{-1}$ ), and related reference crops for estimating biological nitrogen fixation (see Sect. 2.3) were sown in April and cut two times per year according to the development stage of the lucerne crop (Tab. I). Two treatments - two lucerne crops differing in their mulching date - were tested in a completely randomised block design on $5.4 \times 5 \mathrm{~m}$ plots in four replicates on the same trial in the two experimental years. Related reference crops for estimating biological nitrogen fixation of the lucerne crop were placed on adjacent plots of the same size, respectively. Lucerne managed according to conventional practice (conventional treatment $=$ $\mathrm{CT}$ ) was cut at the blooming state (Tab. I). In the natural treatment (NT), the first mulching date was two weeks earlier and the second mulching date was two weeks later in both years to prolong the period without disturbance. Treatments were the same in the first (2004) and the second year of production (2005) (Tab. I). The trial ended with the second cut in July 2005.

Weed colonisation was very low at the experimental farm in Raasdorf. Therefore, the effect of the modified mulching system on weed density was tested on farmers' fields in the vicinity (see Sect. 2.4). Weather data were assessed by the gauging station of the Institute for Agronomy and Plant Breeding, University of Natural Resources and Applied Life Sciences Vienna, in Raasdorf. 
Table I. Maturity stage, plant height and weather conditions of lucerne treatments in the first (2004) and second (2005) years of production. Treatment NT: natural treatment lucerne system, CT: conventional treatment lucerne system; maturity stages (KDC according to Buhtz et al., 1990): 51 = early bud, 57 = late bud stage, 61 = early bloom, 65 = late bloom, 70 = green pod; sum of temperature/precipitation: from start of vegetation period (early April) to first cut and from first to second cut.

\begin{tabular}{|c|c|c|c|c|c|c|}
\hline Date & Cut. & Treatment & Maturity stage (KDC) & Plant height $(\mathrm{cm})$ & Sum of Temp. $\left({ }^{\circ} \mathrm{C}\right)$ & Sum of Precipitation $(\mathrm{mm})$ \\
\hline \multicolumn{7}{|c|}{ 1st year (2004) } \\
\hline 5 July & 1 & NT & 61 & $60-70$ & 1244 & 189 \\
\hline 19 July & 1 & $\mathrm{CT}$ & 65 & $70-85$ & 1507 & 197 \\
\hline 23 Aug. & 2 & $\mathrm{CT}$ & 51 & $25-30$ & 752 & 10 \\
\hline 6 Sept. & 2 & NT & 57 & $25-30$ & 1266 & 34 \\
\hline \multicolumn{7}{|c|}{ 2nd year (2005): } \\
\hline 23 May & 1 & NT & 57 & $40-55$ & 505 & 70 \\
\hline 7 June & 1 & $\mathrm{CT}$ & 65 & $60-80$ & 779 & 86 \\
\hline 11 July & 2 & $\mathrm{CT}$ & 65 & $30-35$ & 635 & 99 \\
\hline 25 July & 2 & NT & 70 & $30-35$ & 1203 & 121 \\
\hline
\end{tabular}

\subsection{Sampling methods and analysis}

Above-ground dry matter (DM) biomass production of lucerne and reference crops was determined by handharvesting $2 \times 0.5 \mathrm{~m}^{2}$ per plot of shoots (cutting height $5 \mathrm{~cm}$ above soil level) and stubbles, and drying an aliquot at $105{ }^{\circ} \mathrm{C}$ to constant weight. For statistical analysis, mean values per plot were calculated. On the rest of the plot, all plant material remained on the field, corresponding to a green manure system. At the second cut, below-ground biomass (two layers: $0-30 \mathrm{~cm}$ and $30-60 \mathrm{~cm}$ ) was derived from samples taken with a root auger $(10 \mathrm{~cm}$ in diameter, $60 \mathrm{~cm}$ deep, with four replicates per plot), and roots were subsequently separated from soil by a hydropneumatic elutriation system (Gillison's Variety Fabrication Inc., USA) through a 760- $\mu$ m mesh sieve. In 2005 , lucerne shoots were separated into leaves and stem, and biomass proportion and $\mathrm{N}$ content were determined separately. Part of the plant material was dried at $60^{\circ} \mathrm{C}$ for $48 \mathrm{~h}$, ground to a fine powder, and analysed for $\mathrm{N}$ content and ${ }^{15} \mathrm{~N}$ isotope ratios in the Competence Centre for Stable Isotopes (University of Göttingen) with an isotope ratio mass spectrometer: ThermoQuest Finnigan DELTA ${ }^{\text {plus }}$ or Finnigan MAT 251.

\subsection{Biological nitrogen fixation}

The biological nitrogen fixation of the legumes was estimated by the ${ }^{15} \mathrm{~N}$ dilution method (Chalk, 1985) using a lowlevel, large-scale application of ${ }^{15} \mathrm{~N}$-enriched fertiliser (according to Reiter et al., 2002). The plant-available soil N pool was enriched with $0.1 \mathrm{~kg}^{15} \mathrm{~N} \mathrm{ha}^{-1}$ by applying a labelled fertiliser $\left(1 \mathrm{~kg} \mathrm{~N} \mathrm{ha}^{-1}\right.$ as potassium nitrate, 10 at. $\left.\%{ }^{15} \mathrm{~N}\right)$ ten days after sowing. To calculate the amount of $\mathrm{N}$ fixed from the legume, a reference crop for each of the two lucerne treatments was cultivated. A grass mixture consisting of false oat ( $\mathrm{Ar}$ rhenatherum elatius), red fescue (Festuca rubra), cocksfoot (Dactylis glomerata) and perennial ryegrass (Lolium perenne) (seeding density $25 \mathrm{~kg} \mathrm{ha}^{-1}$; grass species with $25 \%$ area proportion in the mixture) served as a reference crop. The percentage of legume $\mathrm{N}$ content derived from the atmosphere $\left(\mathrm{N}_{\mathrm{dfa}}\right)$ was calculated using the isotopic differences between the legume and the reference crops as described by Fried and Middelboe (1977; Eq. (1)).

$$
\% \mathrm{~N}_{\mathrm{dfa}}=\left(\frac{1-\text { atom } \%^{15} \text { Nexcess }_{\text {legume }}}{\text { atom } \%{ }^{15} \text { Nexcess }}\right) \times 100
$$

atom $\%{ }^{15} \mathrm{~N}$ excess $=$ atom $\%{ }^{15} \mathrm{~N}$ (legume or reference crop) -0.3663

The equation for calculating the amount of $\mathrm{N}$ from Nfix at the first cut was:

$$
\mathrm{Nfix}_{\mathrm{C} 1}\left(\mathrm{~kg} \mathrm{ha}^{-1}\right)=\mathrm{N}_{\mathrm{SC} 1}\left(\mathrm{~kg} \mathrm{ha}^{-1}\right) \times\left(\frac{\% \mathrm{Ndfa}_{\mathrm{SC} 1}}{100}\right)
$$

where

$\mathrm{Nfix}_{\mathrm{C} 1}=$ amount of $\mathrm{N}$ from Nfix in the legume shoots at the first cut.

$\% \mathrm{Ndfa}_{\mathrm{SC} 1}=$ nitrogen derived from the atmosphere in the shoot at the first cut.

$\mathrm{N}_{\mathrm{SC} 1}=\mathrm{DM}$ yield of legume shoots $\mathrm{x}$ shoot $\mathrm{N}$ content at the first cut.

The Nfix at the second cut was calculated by summing the amount of $\mathrm{N}$ from Nfix in shoots, stubbles and roots at that time according to Pietsch et al. (2007). The seasonal nitrogen fixation value (Nfix total) is the sum of Nfix at the first and second cuts.

\subsection{Weed colonisation}

To reliably test whether shifting the mulching date influences the weed colonisation of the crop, four organic lucerne fields in the Marchfeld region (Lassee) with similar conditions but more weed coverage than in Raasdorf were selected. Lucerne was established in spring as a pure crop on fields. Each field was divided into two parts, differing in mulching date (for treatments see Tab. I). On every field and treatment, three $25-\mathrm{m}^{2}$ plots were selected. On every plot, weed abundance was visually estimated at each cut (June, August) with the method of Braun-Blanquet (1964). We used a modified Braun-Blanquet scale with cover degree 1 divided into $1 \mathrm{a}, 1 \mathrm{~b}$ and $1 \mathrm{~m}$ and cover degree 2 divided into $2 \mathrm{a}$ and $2 \mathrm{~b}$ (Dierschke, 1994). The fieldwork was carried out in summer 2004. 


\subsection{Statistical analysis}

Data for biological nitrogen fixation, dry-matter and $\mathrm{N}$ yield, $\mathrm{N}$ content and leaf/stem biomass proportion were analysed statistically by a two-way analysis of variance (ANOVA; $P<0.05)$ with the factors 'treatment' and 'block'. For the factor 'treatment', significance from the table of variances was used. For pairwise comparisons of the means of the factor 'block', a Tukey test was used. Additionally, an alternative model, a special form of covariance analysis with the factor 'treatment' and the 'block' number as a covariate, was applied. This approach was suggested by Moder (1998) to improve the test efficiency by gaining additional degrees of freedom for estimating the error variance. It improved the test efficiency in most cases. When not mentioned in the text, the factor 'block' had no significant effect on the tested traits. To statistically analyse differences in weed pressure between natural and conventional treatments, only weed species occurring on at least two fields were used. In a first step, the cover degrees were transformed into numerical values according to Dierschke (1994) to calculate the mean coverage of each weed species of the three plots per field and treatment. In a second step, the calculated mean coverage of each weed species was retransformed into the Braun-Blanquet classes. Due to different weed species composition, all calculations were done for each field separately. Using Fischer's exact test (significance level $P=0.05$ ) we compared the frequencies of the occupied Braun-Blanquet classes of the two treatments, combining all weed species. This analysis was done for the first and second cuts in 2004. All statistical analyses were carried out with SPSS 12.0.

\section{RESULTS AND DISCUSSION}

\subsection{Weather conditions}

The temperature course from August to November 2004 and from May to July 2005 was above the long-term average (data not shown). On the other hand, the annual precipitation was below the long-term mean values in both vegetation periods (2004: $-36 \mathrm{~mm}$; 2005: $-107 \mathrm{~mm})$. Weather conditions, especially precipitation, differed considerably in the two experimental years: while from April to June (sowing to first cut) 2004 the precipitation was higher than in the respective period in 2005, from July to August (between first and second cuts) it was lower in the first than in the second year of production (Fig. 1).

\subsection{Development and biomass production}

Because of the cold and wet conditions in spring 2004, lucerne was sown in mid-April. After 81/95 days, the plants were in early bloom (natural treatment) / full bloom stage (conventional treatment) in July (Tab. I). In the second production year (2005), the plants naturally had an advantage in development: the period from the beginning of the vegetation
Precipitation (day $\mathrm{mm}^{-1}$ )

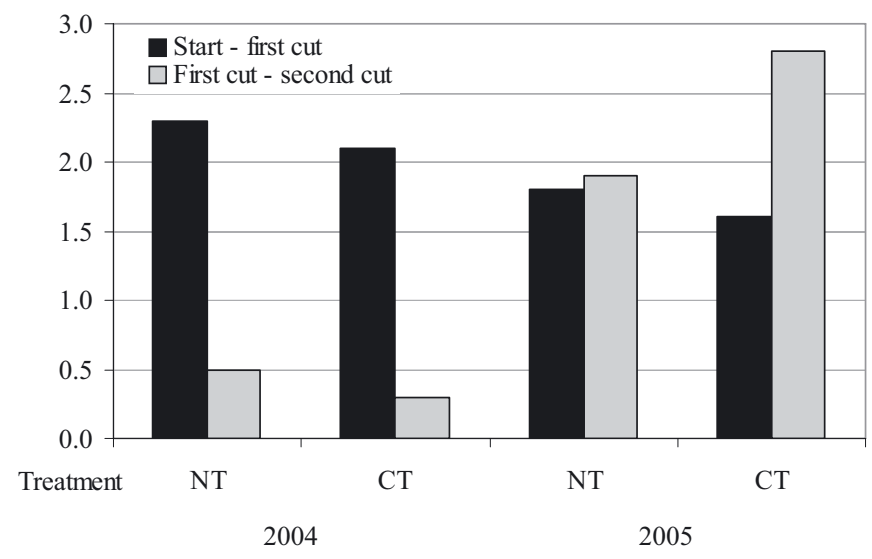

Figure 1. Different precipitation conditions (precipitation per day in $\mathrm{mm}$ ) in the two production years in Raasdorf: decrease in the first year, 2004, and increase in the second year, 2005, from the start (beginning of vegetation period: 15 April) - first cut period and from first cut - second cut period of lucerne treatments (NT: natural treatment, CT: conventional treatment).

period in April to the first cut was only 38-53 days. Therefore, the accumulated sum of temperature and precipitation at the first cut in 2004 was twice that of 2005 (Tab. I).

At the first cut in 2004, the shoot dry-matter yield of the later-mulched conventional treatment reached $4.6 \mathrm{t} \mathrm{ha}^{-1}$ and is significantly higher than that of the earlier-mulched natural treatment treatment $\left(3.2 \mathrm{tha}^{-1}\right)$. No differences between the treatments were found in shoot dry-matter yield at the first cut in 2005 (Tab. II). Precipitation was higher from April to July 2004 than in 2005 . The plants received an average precipitation rate of $2.2 \mathrm{~mm}$ per day from the start of the vegetation period to the first cut in 2004, whereas in 2005 it rained only $1.7 \mathrm{~mm}$ per day (Fig. 1). More humid conditions in summer 2004 effected a longer development period (by 14 days) in the conventional treatment, which is reflected in the higher shoot dry-matter yield of this treatment. In summer 2005, the conditions from April to the first cut were too dry to show an advantage in the biomass yield of the later-mulched conventional treatment. Besides, minor deer damage in the later-mulched conventional treatment at the first cut reduced shoot biomass development.

In 2005, the period between the first and second cuts showed a higher precipitation rate than in 2004 (2.4 versus $0.4 \mathrm{~mm} \mathrm{day}^{-1}$, Fig. 1). This was reflected in a slightly higher shoot dry-matter yield of the later-harvested natural treatment at the second cut, but the difference was not significant (Tab. II). In 2004, the period before the second cut was too dry to show a differentiating effect on the two treatments. This agrees with the results of Stein-Bachinger et al. (2001), who found no differences in yield between the common and later forage cut treatment because extremely dry conditions up to seven weeks after the first cut caused almost no biomass increase. In both production years, the period from the first to the second cut was 63 days in the natural treatment and 35 days 
Table II. Dry matter (DM) yield of lucerne shoots, stubbles and roots in the first (2004) and second (2005) years of production. Root yield 0-60 cm, Residues: stubbles and roots; NT: natural treatment, CT: conventional treatment; SD: standard deviation. Mean values in one column, cut and year with the same letter do not differ significantly $(P<0.05)$.

\begin{tabular}{|c|c|c|c|c|c|c|c|}
\hline \multirow[t]{2}{*}{ Year } & \multirow[t]{2}{*}{ Treatment } & \multicolumn{3}{|c|}{ Shoot yield t DM ha $^{-1}$} & Stubble yield t DM ha ${ }^{-1}$ & Root yield t DM ha- & Residue yield t DM ha- \\
\hline & & 1 st cut & 2nd cut & Total & \multicolumn{3}{|c|}{ 2nd cut } \\
\hline \multirow[t]{4}{*}{2004} & NT & $3.19 \mathrm{~b}$ & $1.21 \mathrm{a}$ & $4.40 \mathrm{~b}$ & $0.60 \mathrm{a}$ & $4.78 \mathrm{a}$ & $5.38 \mathrm{a}$ \\
\hline & $S D \pm$ & 0.25 & 0.20 & 0.41 & 0.09 & 3.36 & 3.35 \\
\hline & CT & $4.64 \mathrm{a}$ & $1.41 \mathrm{a}$ & $6.05 \mathrm{a}$ & $0.74 \mathrm{a}$ & $8.76 \mathrm{a}$ & $9.50 \mathrm{a}$ \\
\hline & $S D \pm$ & 0.30 & 0.27 & 0.53 & 0.18 & 3.34 & 3.25 \\
\hline \multirow[t]{4}{*}{2005} & NT & $3.08 \mathrm{a}$ & $1.64 \mathrm{a}$ & $4.72 \mathrm{a}$ & $0.91 \mathrm{a}$ & $11.11 \mathrm{a}$ & $12.02 \mathrm{a}$ \\
\hline & $S D \pm$ & 0.57 & 0.93 & 1.22 & 0.01 & 1.63 & 1.62 \\
\hline & $\mathrm{CT}$ & $2.42 \mathrm{a}$ & $1.09 \mathrm{a}$ & $3.51 \mathrm{a}$ & $1.07 \mathrm{a}$ & $10.57 \mathrm{a}$ & $11.64 \mathrm{a}$ \\
\hline & $S D \pm$ & 0.76 & 0.24 & 0.60 & 0.30 & 0.69 & 0.97 \\
\hline
\end{tabular}

in the conventional treatment. Nevertheless, plants in the first year, 2004, were in earlier maturity stages after this period than in 2005 (Tab. I). The low precipitation between the two cuts (Fig. 1) limited water supply and impaired the phenological plant development in the two treatments. Water stress typically slows maturation of forages (Buxton, 1996). Martiniello et al. (1997) also described the influence of limited water supply on the plant development in an early cut treatment of lucerne.

At the second cut, the lucerne residues reached 5.38 (natu-

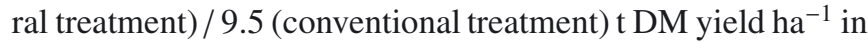
2004 and 12.02 (natural treatment) / 11.64 (conventional treatment) t DM yield ha ${ }^{-1}$ in 2005. The differences between the treatments (Tab. II) were not significant in both years of production (significant between-'block' differences in DM root yield and DM residue yield in 2005). Lucerne mulched at the early maturity stage for nature conservation showed a significantly lower herbage production compared with the later maturity stage in the conventional treatment at the first cut in the more humid first production year. Other authors also described higher lucerne yields at later cutting dates compared with early harvesting (Latheef et al., 1988; Avice et al., 1997; Martiniello et al., 1997; Lloveras et al., 1998). The length of the interval between the two cuts had no visible influence on the herbage production at the second cut in our study. In contrast, Avice et al. (1997) found that a longer spring regrowth period positively affected subsequent shoot regrowth during summer. Leach (1968) also demonstrated that later-harvested lucerne had a more rapid rate of regrowth. Short regrowth cycles in a lucerne grazing system reduced annual shoot yield compared with long regrowth cycles in two experimental years (Teixeira et al., 2007). Contrary to our study, the lucerne plants were irrigated in both those field experiments. We conclude that increasing the length between two cuts positively influenced yield only when soil moisture conditions were optimal for plant growth. The total forage dry-matter accumulation could be attributed mainly to stem dry-matter accumulation. The greater leaf/stem biomass proportion of the natural treatment at the first cut (1.26, not significant) and of the conventional treatment at the second cut (1.86; significant differences in factors 'treatment' and 'block') indicated that the proportion of lucerne stems increased with preceding development in the second year of production (Tab. III; no data in first year of production). The leaf/stem biomass proportion decreases as
Table III. Nitrogen (N) content and leaf/stem biomass proportion in lucerne shoots in the second year (2005) of production. NT: natural treatment, CT: conventional treatment; SD: standard deviation. Mean values in one column, cut and year with the same letter do not differ significantly $(P<0.05)$.

\begin{tabular}{|c|c|c|c|c|c|c|c|}
\hline \multirow[t]{3}{*}{ Year } & \multirow[t]{3}{*}{ Treatment } & \multicolumn{2}{|c|}{$\begin{array}{c}\text { Leaf/stem } \\
\text { biomass proportion }\end{array}$} & \multicolumn{4}{|c|}{$\mathrm{N}$ content $\%$} \\
\hline & & \multirow[t]{2}{*}{ 1st cut } & \multirow[t]{2}{*}{ 2nd cut } & 1 st cut & 1 st cut & 2nd cut & 2nd cut \\
\hline & & & & Leaf & Stem & Leaf & Stem \\
\hline \multirow[t]{4}{*}{2005} & NT & $1.26 \mathrm{a}$ & $1.66 \mathrm{~b}$ & $4.30 \mathrm{a}$ & $1.43 \mathrm{a}$ & $4.48 \mathrm{a}$ & $1.60 \mathrm{a}$ \\
\hline & $S D \pm$ & 0.17 & 0.17 & 0.19 & 0.19 & 0.13 & 0.29 \\
\hline & $\mathrm{CT}$ & $1.04 \mathrm{a}$ & $1.86 \mathrm{a}$ & $4.12 \mathrm{a}$ & $1.33 \mathrm{a}$ & $4.63 \mathrm{a}$ & $1.75 \mathrm{a}$ \\
\hline & $S D \pm$ & 0.23 & 0.21 & 0.06 & 0.16 & 0.21 & 0.13 \\
\hline
\end{tabular}

plants mature (Martiniello et al., 1997; Sheaffer et al., 2000; Lamb et al., 2003). Sheaffer et al. (2000) found the highest leaf yield in an early flower and the highest stem yield in the late flower cut regime. Nevertheless, leaf yield was higher than stem yield in both treatments and both cuts in our study.

\subsection{Nitrogen content and nitrogen yield}

The $\mathrm{N}$ content of lucerne shoots ranged from 2.9 to $4.6 \%$ $\mathrm{N}$ and did not differ between the treatments in both years and at both cuts (Tab. IV; significant between- 'block' difference in shoot $\mathrm{N}$ content at the second cut in 2004). The greater shoot dry-matter yield of the conventional treatment at the first cut in 2004 corresponds to an increased shoot $\mathrm{N}$ yield $(136 \mathrm{~kg} \mathrm{~N}$ $\mathrm{ha}^{-1}$ ) compared with the natural treatment $\left(92 \mathrm{~kg} \mathrm{~N} \mathrm{ha}^{-1}\right)$. No between-treatment differences in shoot $\mathrm{N}$ yield were recorded at the second cut in 2004 or both cuts in 2005 (Tab. IV). In lucerne leaves, we found $4.1-4.6 \% \mathrm{~N}$, and in the stem about $1.3-1.8 \% \mathrm{~N}$, but there were no differences between the treatments (Tab. III; significant 'block' effect for leaf $\mathrm{N}$ content at the second cut in 2005).

In the second year of production, the $\mathrm{N}$ content in the total herbage (leaves and stems) decreased with the preceding maturity of plants, but the difference between the treatments was not significant (Tab. IV). Declines in crude protein (CP) concentration and general nutritive quality of forages as the plants mature are well documented (Sheaffer et al., 2000; De Santis 
Table IV. Nitrogen $(\mathrm{N})$ content and nitrogen yield in lucerne shoots at the first and second cuts and in stubbles and roots at the second cut in the first (2004) and second (2005) years of production. St: Stubbles, R: Roots 0-60 cm, NT: natural treatment, CT: conventional treatment; SD: standard deviation. Mean values in one column, cut and year with the same letter do not differ significantly $(P<0.05)$.

\begin{tabular}{|c|c|c|c|c|c|c|c|c|c|c|c|}
\hline \multirow[t]{3}{*}{ Year } & \multirow[t]{3}{*}{ Treatment } & \multicolumn{5}{|c|}{ Shoot } & \multicolumn{5}{|c|}{ Residues } \\
\hline & & \multicolumn{2}{|c|}{$\begin{array}{c}\text { N content } \\
\%\end{array}$} & \multicolumn{3}{|c|}{$\begin{array}{l}\text { Nitrogen yield } \\
\mathrm{kg} \mathrm{N} \mathrm{ha}^{-1}\end{array}$} & \multicolumn{2}{|c|}{$\begin{array}{c}\mathrm{N} \text { content } \\
\%\end{array}$} & \multicolumn{3}{|c|}{$\begin{array}{l}\text { Nitrogen yield } \\
\mathrm{kg} \mathrm{N} \mathrm{ha}^{-1}\end{array}$} \\
\hline & & 1st cut & 2nd cut & 1st cut & 2nd cut & Total & St & $\mathrm{R}$ & St & $\mathrm{R}$ & Total \\
\hline \multirow{4}{*}{2004} & NT & $2.88 \mathrm{a}$ & $3.36 \mathrm{a}$ & $92 \mathrm{~b}$ & $41 \mathrm{a}$ & $133 \mathrm{~b}$ & $2.70 \mathrm{a}$ & $2.17 \mathrm{a}$ & $16 \mathrm{a}$ & $114 \mathrm{a}$ & $131 \mathrm{a}$ \\
\hline & $S D \pm$ & 0.42 & 0.62 & 16 & 9 & 18 & 0.46 & 0.24 & 5 & 85 & 85 \\
\hline & $\mathrm{CT}$ & $2.93 \mathrm{a}$ & $2.91 \mathrm{a}$ & $136 \mathrm{a}$ & $41 \mathrm{a}$ & $177 \mathrm{a}$ & $2.08 \mathrm{a}$ & $1.89 \mathrm{~b}$ & $16 a$ & $175 \mathrm{a}$ & $191 \mathrm{a}$ \\
\hline & $S D \pm$ & 0.13 & 0.64 & 9 & 11 & 12 & 0.18 & 0.07 & 5 & 78 & 76 \\
\hline \multirow[t]{4}{*}{2005} & NT & $3.49 \mathrm{a}$ & $4.27 \mathrm{a}$ & $108 \mathrm{a}$ & $68 \mathrm{a}$ & $176 a$ & $2.64 \mathrm{a}$ & $1.51 \mathrm{a}$ & $24 \mathrm{a}$ & $169 \mathrm{a}$ & $193 \mathrm{a}$ \\
\hline & $S D \pm$ & 0.12 & 0.33 & 19 & 34 & 45 & 0.24 & 0.09 & 2 & 13 & 13 \\
\hline & $\mathrm{CT}$ & $3.41 \mathrm{a}$ & $4.55 \mathrm{a}$ & $82 \mathrm{a}$ & $50 \mathrm{a}$ & $131 \mathrm{a}$ & $2.60 \mathrm{a}$ & $1.59 \mathrm{a}$ & $27 \mathrm{a}$ & $166 \mathrm{a}$ & $194 \mathrm{a}$ \\
\hline & $S D \pm$ & 0.18 & 0.09 & 24 & 11 & 17 & 0.30 & 0.16 & 7 & 20 & 26 \\
\hline
\end{tabular}

et al., 2004). Maturity influences forage quality more than any other factors (Buxton, 1996). A later first cut increased forage yield, but the crude protein content decreased significantly (Stein-Bachinger et al., 2001). The leaf N contents were two to three times higher than stem $\mathrm{N}$ contents at all growth stages. As plants grow they have a higher proportion of structural tissues (stem), which contain little nitrogen (Lemaire et al., 1992). Thus, the $\mathrm{N}$ yield in shoot biomass should decrease as plant biomass increases. In our study, this was not the case because shoot $\mathrm{N}$ content was not reduced significantly in either year. The $\mathrm{N}$ content of roots at the second cut in 2004 was significantly higher in the natural treatment $(2.17 \% \mathrm{~N})$ than in the conventional treatment $(1.89 \% \mathrm{~N})$. The stubble biomass contained the same amount of $\mathrm{N}$ in both treatments and years, leading to similar stubble $\mathrm{N}$ yield (Tab. IV). The total amount of $\mathrm{N}$ in the lucerne residues at the end of the vegetation period was $131-194 \mathrm{~kg} \mathrm{~N} \mathrm{ha}^{-1}$.

In the second year of production (2005) at the first cut we also determined biomass yield and $\mathrm{N}$ content of roots (data not shown). The $\mathrm{N}$ contents were significantly higher in the conventional than the natural treatment $(2.1 \%$ versus $1.6 \% \mathrm{~N}$ at 0-60 cm depth). Values in the root biomass (0-30 cm depth) were $214 \mathrm{~kg} \mathrm{~N} \mathrm{ha}^{-1}$ in the conventional and $136 \mathrm{~kg} \mathrm{~N} \mathrm{ha}^{-1}$ in the natural treatment. Because of the longer spring growing period, the former plants accumulated more $\mathrm{N}$ reserves here.

Generally, lucerne shoot regrowth is largely determined by the root TNC (total non-structural carbohydrates) level (Volenec, 1999). Recent work suggests that regrowth after shoot removal may depend more on the availability of $\mathrm{N}$ reserves in roots and crowns than of C reserves (Kim et al., 1993; Avice et al., 1996, 1997). Full bloom cuts allowed greater autumn regrowth than late bud cuttings, possibly due to higher root reserve accumulation during the mid-season cuts (Gossen et al., 1994). The $\mathrm{N}$ and starch storage of frequently cut taproots was smaller than of plants with a 45-day defoliation interval (Avice et al., 1997). A six-week regrowth period was generally required to fully restore root $\mathrm{N}$ content (Lemaire et al., 1992).

In our study, the cutting interval between the first and second cuts was shorter in the conventional versus the natural treatment (65/93 days). The longer regrowth period of the lat- ter allowed the plants to take advantage of radiation, temperature and precipitation (Tab. I). On the other hand, roots in the conventional treatment had greater $\mathrm{N}$ reserves before regrowth. Nevertheless, the shoot biomass yield of both treatments did not differ at the second cut in 2005. We therefore assume that regrowth duration and root $\mathrm{N}$ reserve amounts in lucerne had opposite effects on shoot regrowth, cancelling each other out.

\subsection{Biological nitrogen fixation}

At the first cut in 2004, nitrogen fixation was significantly higher in the conventional than in the natural treatment (109 versus $65 \mathrm{~kg} \mathrm{~N}^{-1}$; Fig. 2). This reflects the increased shoot dry-matter yield of the former and the role of yield in calculating biological nitrogen fixation. The shoot dry-matter yield of the natural treatment was just slightly higher (not significant, see Tab. II) than of the conventional treatment at the first cut in 2005. Nevertheless, nitrogen fixation was significantly higher in the natural than conventional treatment (73 versus $60 \mathrm{~kg} \mathrm{~N}$ $\mathrm{ha}^{-1}$; Fig. 2). In both production years, nitrogen fixation did not differ significantly between the treatments at the second cut (Fig. 2).

The seasonal amount of nitrogen fixation is more important for supplying $\mathrm{N}$ to the following crops than Nfix of a single cut. In total, 200-265 $\mathrm{kg} \mathrm{N}^{-1}$ in 2004 and 228$260 \mathrm{~kg} \mathrm{~N} \mathrm{ha}^{-1}$ in 2005 were fixed from the atmosphere by lucerne: the treatments did not differ from one another. The yield-independent $\mathrm{N}_{\mathrm{dfa}}$ value reached $66-75 \%$ in the first and $60-72 \%$ in the second year of production; again, treatment made no difference (Tab. V).

The nitrogen fixation process in root nodules may require as much as $50 \%$ of the photosynthates produced by legume plants (e.g. cowpea; Pate and Herridge, 1978); this process is highly dependent on a continuous supply from the shoot for energy to support nodule function and growth (Ta and Faris, 1987). Defoliation removes most of the photosynthetic area of lucerne (Avice et al., 1996). Due to a shortage of stored C (Avice et al., 1996) and the competition between vegetative regrowth and nodules for reserve carbohydrates and current 


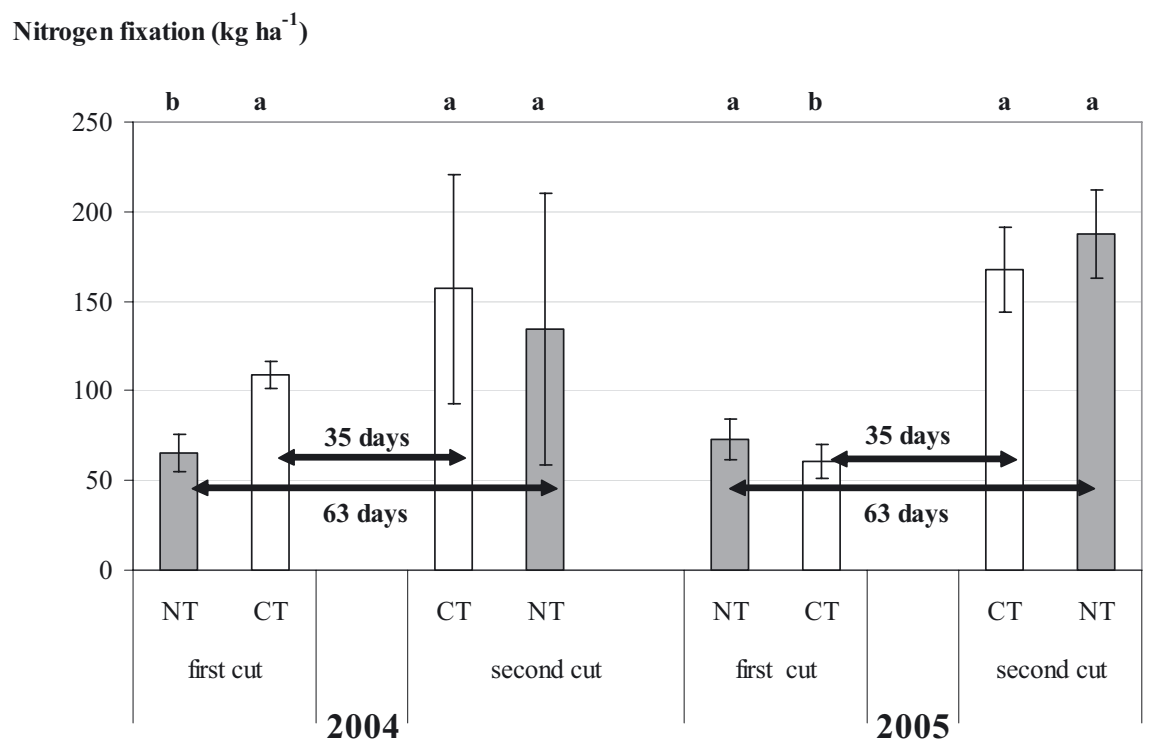

Figure 2. Comparison of natural treatment (NT) and conventional treatment (CT) lucerne systems in terms of biological nitrogen fixation (kg $\mathrm{N} \mathrm{ha}^{-1}$ ) at the first and second cuts in 2004 and 2005. Error bar: standard deviation. Mean values with the same letter do not differ significantly $(P<0.05)$.

Table V. Seasonal amount of $\mathrm{N}$ from biological nitrogen fixation (Nfix total = sum of Nfix at cuts 1 and 2 ) and nitrogen derived from the atmosphere $\left(\mathrm{N}_{\mathrm{dfa}}\right)$ of lucerne at the first and second cuts in the first (2004) and second (2005) years of production, NT: natural treatment, CT: conventional treatment; SD: standard deviation. Mean values in one column, cut and year with the same letter do not differ significantly $(P<0.05)$.

\begin{tabular}{ccccc}
\hline Year & Treatment & Nfixkg ha $^{-1}$ & \multicolumn{2}{c}{$\mathrm{N}_{\text {dfa }} \%$} \\
\hline 2004 & & Total & 1 st cut & 2nd cut \\
& $\mathrm{NT}$ & $200 \mathrm{a}$ & $66 \mathrm{a}$ & $75 \mathrm{a}$ \\
& $S D \pm$ & 86 & 6 & 10 \\
& $\mathrm{CT}$ & $265 \mathrm{a}$ & $73 \mathrm{a}$ & $67 \mathrm{a}$ \\
& $S D \pm$ & 62 & 5 & 7 \\
\hline 2005 & $\mathrm{NT}$ & $260 \mathrm{a}$ & $60 \mathrm{a}$ & $72 \mathrm{a}$ \\
& $S D \pm$ & 29 & 1 & 6 \\
& $\mathrm{CT}$ & $228 \mathrm{a}$ & $63 \mathrm{a}$ & $69 \mathrm{a}$ \\
& $S D \pm$ & 28 & 8 & 4 \\
\hline
\end{tabular}

photosynthates, defoliation strongly reduces nitrogenase activity during the first 14 days of regrowth (Cralle and Heichel, 1981). After defoliation of forage legumes, $\mathrm{N}$ reserves are required to initiate new shoot growth (Kim et al., 1993). Several weeks before net photosynthesis peaks at the flowering stage, the specific activity of $\mathrm{N}$ fixation by cowpea (Vigna unguiculata $\mathrm{L}$.) nodules was reduced while nodule mass was still increasing (Herridge and Pate, 1977). Assuming similar processes in lucerne, our data confirm $\left(\mathrm{N}_{\mathrm{dfa}}, \mathrm{Tab} . \mathrm{V}\right)$ that plants mulched at later maturity stages (conventional treatment at the first cut and natural treatment at the second cut) fixed the same percentage of $\mathrm{N}$ from the atmosphere as plants mulched at earlier maturity stages (natural treatment at the first cut and conventional treatment at the second cut). This means that the yield-independent $\mathrm{N}_{\mathrm{dfa}}$ value was not affected by the plants' maturity stage at harvest. An earlier study at the experimental station in Raasdorf (Pietsch et al., 2007) revealed similar Nfix and $\mathrm{N}_{\mathrm{dfa}}$ values in a perennial green manure lucerne system (Nfix: $159-211 \mathrm{~kg} \mathrm{~N} \mathrm{ha}^{-1} ; \mathrm{N}_{\mathrm{dfa}}: 48-56 \%$ ) like in the present study. The Nfix in $\mathrm{kg} \mathrm{ha}^{-1}$ depends on the produced biomass yield. Accordingly, we estimated a significantly higher Nfix in the conventional (versus natural) treatment at the first cut in 2004, when its shoot dry-matter yield was also higher.

The higher Nfix at the first cut and the lack of a difference between treatments at the second cut reflect weather conditions in 2004. These results can only be expected in vegetation periods with sufficient water supply until the first cut and with drier conditions between the first and second cuts (scenario 2, Tab. VI). In all other scenarios (scenario 1, 3 and 4, Tab. VI), the natural treatment should reach the same amount of fixed nitrogen as the conventional treatment. The results from 2005, with weather conditions described in scenario 3, confirm this interpretation. We conclude that the natural treatment of lucerne has no disadvantages compared with the conventional treatment in three out of four weather scenarios regarding biological nitrogen fixation. Therefore, the pre-crop effect of lucerne, which is important in an organic crop rotation to provide the subsequent crops with $\mathrm{N}$, should be similar in most cases.

\subsection{Weed colonisation}

According to the defined requirements (occurrence on at least two fields), 11 out of the 36 recorded weed species were used to compare the influence of mulching date on weed coverage: Amaranthus retroflexus L., Chenopodium album L., Chenopodium hybridum L., Cirsium arvense L., 
Table VI. Effects of weather conditions on the amount of biological nitrogen fixation (Nfix, $\mathrm{kg} \mathrm{ha}^{-1}$ ) of lucerne in a natural (NT) and a conventional treatment (CT) system -4 scenarios.

\begin{tabular}{|c|c|c|c|c|c|}
\hline & & \multicolumn{4}{|c|}{ Weather conditions until 1st cut } \\
\hline & \multirow{5}{*}{ Dry } & \multicolumn{2}{|c|}{ Dry } & \multicolumn{2}{|c|}{ Humid } \\
\hline \multirow{8}{*}{$\begin{array}{c}\text { Weather } \\
\text { conditions from } \\
\text { 1st to } 2 \text { nd cut }\end{array}$} & & \multicolumn{2}{|c|}{ Scenario 1: Nfix } & \multicolumn{2}{|c|}{ Scenario 2: Nfix $\quad(=2004)$} \\
\hline & & Cut 1: & $\mathrm{NT} \leqslant \mathrm{CT}$ & Cut 1: & $\mathrm{NT}<\mathrm{CT}$ \\
\hline & & Cut 2: & $\mathrm{NT}=\mathrm{CT}$ & Cut 2: & $\mathrm{NT}=\mathrm{CT}$ \\
\hline & & Total: & $\mathrm{NT}=\mathrm{CT}$ & Total: & $\mathrm{NT} \leqslant \mathrm{CT}$ \\
\hline & \multirow[t]{4}{*}{ Humid } & Scen & $(=2005)$ & \multicolumn{2}{|c|}{ Scenario 4: Nfix } \\
\hline & & Cut 1: & $\mathrm{NT} \leqslant \mathrm{CT}$ & Cut 1: & $\mathrm{NT}<\mathrm{CT}$ \\
\hline & & Cut 2: & $\mathrm{NT} \geqslant \mathrm{CT}$ & Cut 2: & $\mathrm{NT} \geqslant \mathrm{CT}$ \\
\hline & & Total: & $\mathrm{NT}=\mathrm{CT}$ & Total: & $\mathrm{NT}=\mathrm{CT}$ \\
\hline
\end{tabular}

Table VII. Frequencies of occupied classes at the first cut and second cut in 2004. NT: natural treatment, CT: conventional treatment.

\begin{tabular}{|c|c|c|c|c|c|c|c|c|}
\hline \multirow{2}{*}{$\begin{array}{l}\text { Braun-Blanquet } \\
\text { classes }\end{array}$} & \multicolumn{2}{|c|}{ Field A } & \multicolumn{2}{|c|}{ Field B } & \multicolumn{2}{|c|}{ Field C } & \multicolumn{2}{|c|}{ Field D } \\
\hline & NT & CT & NT & $\mathrm{CT}$ & NT & $\mathrm{CT}$ & NT & $\mathrm{CT}$ \\
\hline \multicolumn{9}{|l|}{1 st cut } \\
\hline 0 & 1 & 1 & - & - & 0 & 4 & - & - \\
\hline$r$ & 3 & 3 & 2 & 2 & 4 & 1 & 1 & 1 \\
\hline+ & 0 & 2 & 2 & 4 & - & - & 2 & 0 \\
\hline $1 \mathrm{a}$ & 2 & 0 & 1 & 0 & 3 & 2 & 2 & 2 \\
\hline $1 b$ & - & - & 1 & 2 & - & - & 0 & 2 \\
\hline $1 \mathrm{~m}$ & - & - & 2 & 1 & 1 & 0 & - & - \\
\hline $2 \mathrm{a}$ & - & - & 1 & 0 & 0 & 1 & 1 & 0 \\
\hline $2 b$ & 1 & 0 & - & - & - & - & 0 & 1 \\
\hline 3 & 0 & 1 & - & - & - & - & - & - \\
\hline \multicolumn{9}{|c|}{ Fischer's exact test - significance } \\
\hline & \multicolumn{2}{|c|}{0.487} & \multicolumn{2}{|c|}{0.867} & \multicolumn{2}{|c|}{0.099} & \multicolumn{2}{|c|}{0.463} \\
\hline \multicolumn{9}{|l|}{ 2nd cut } \\
\hline 0 & 2 & 0 & 2 & 0 & 1 & 0 & - & - \\
\hline $\mathrm{r}$ & 3 & 3 & 2 & 3 & 2 & 4 & 1 & 2 \\
\hline+ & 0 & 1 & 1 & 0 & 1 & 0 & 1 & 0 \\
\hline $1 \mathrm{a}$ & 1 & 2 & 0 & 3 & - & - & 1 & 0 \\
\hline $1 \mathrm{~b}$ & - & - & 1 & 0 & - & - & - & - \\
\hline $1 \mathrm{~m}$ & 1 & 1 & - & - & - & - & 0 & 1 \\
\hline \multicolumn{9}{|c|}{ Fischer's exact test - significance } \\
\hline & \multicolumn{2}{|c|}{0.755} & \multicolumn{2}{|c|}{0.145} & \multicolumn{2}{|c|}{0.429} & \multicolumn{2}{|c|}{1.000} \\
\hline
\end{tabular}

Galium aparine L., Papaver rhoeas L., Polygonum convolvulus L., Silene noctiflora L., Stachys annua L., Stellaria media L. and Viola arvensis Murray. On each of the four fields, Galium aparine, Stellaria media and Chenopodium album were common. The weed coverage was generally low and differed slightly between the fields (Tab. VII). Neither at the first nor second cut in 2004 were significant differences in weed coverage found between the natural and the conventional treatment in any field. This agrees with the results of Latheef et al. (1988), who reported no consistent differences in weed coverage in lucerne forage at the first cut among different cut management regimes.

The weed coverage at the second cut is clearly lower (max. Braun-Blanquet class is $1 \mathrm{~m}$ ) than at the first cut (max. BraunBlanquet class is 3; Tab. VII). Based on the lack of difference in weed coverage between the natural and conventional treatments at the second cut, lucerne can apparently outcompete the weeds independently of the first mulching date. Generally, the optimum timing for mechanical weed control is influenced by the crop's competitive ability (Turner et al., 1999) and the growth stage of the weeds (Pullen and Cowell, 1997). For the investigated lucerne fields, it can be shown that the different weed growth stages in the earlier natural treatment cut and the later conventional treatment cut has no influence on weed pressure throughout the vegetation season. Furthermore, an earlier mulching date reduces the risk of weed seeding and has competitive advantages for the crops regarding water, nutrient and light resources. Therefore, lucerne could be mulched earlier than common practice at the first cut without disadvantages for weed control.

\section{CONCLUSION}

Shifting the mulching dates of lucerne - optimised with respect to nature conservation by prolonging the time without disturbance - has no overall disadvantageous effects on lucerne productivity and provides the same amount of $\mathrm{N}$ for following crops compared with the conventional practice in organic farming under pannonian site conditions. The shoot dry matter, $\mathrm{N}$ yield and the amount of fixed nitrogen in lucerne were lower in the earlier-mulched natural treatment at the first cut in the first year of production. Nonetheless, both the seasonal amount of nitrogen fixation and the percentage of $\mathrm{N}$ derived from the atmosphere $\left(\mathrm{N}_{\mathrm{dfa}}\right)$ did not differ between the treatments. A two-weeks-earlier mulching date at the first cut and two-weeks-later mulching date at the second cut of the natural treatment do not negatively affect weed pressure. We therefore recommend shifting mulching dates and prolonging cut intervals in lucerne to protect important wildlife species at organic farms in the Marchfeld region.

Acknowledgements: We gratefully acknowledge the staff of the research station of the University of Natural Resources and Applied Life Sciences in Gross-Enzersdorf for assistance with field work at the experimental site. The technical assistance of C. Gabler and S. Zeidler and the scientific support of G. and B. Schmutzer are also gratefully acknowledged. Thanks are extended to R. Langel (Competence Centre for Stable Isotopes, University of Göttingen) for ${ }^{15} \mathrm{~N}$ analyses and the Institute for Agronomy and Plant Breeding (University of Natural Resources and Applied Life Sciences, Vienna) for use of the climate data from the Raasdorf gauging station. Thanks are due to J. Kelemen-Finan from the 'Distelverein' for the excellent collaboration and perfect project management within this research project and the Austrian 
'Lebensministerium' for supporting this study. M. Stachowitsch proofread the English text.

\section{REFERENCES}

Avice J.C., Ourry A., Lemaire G., Boucaud J. (1996) Nitrogen and carbon flows estimated by ${ }^{15} \mathrm{~N}$ and ${ }^{13} \mathrm{C}$ pulse-chase labelling during regrowth of alfalfa, Plant Physiol. 112, 281-290.

Avice J.C., Lemaire G., Ourry A., Boucaud J. (1997) Effects of the previous shoot removal frequency on subsequent shoot regrowth in two Medicago sativa L. Cultivars, Plant Soil 188, 189-198.

Berdahl J.D., Karn J.F., Hendrickson J.R. (2004) Nutritive quality of coolseason grass monocultures and binary grass-alfalfa mixtures at late harvest, Agron. J. 96/4, 951-955.

Braun-Blanquet J. (1964) Pflanzensoziologie. Grundzüge der Vegetationskunde, Springer, Wien.

Buhtz E., Boese L., Grunert C., Hamann W. (1990) Koordinierter Dezimalcode (KDC) der phänologischen Entwicklung für landwirtschaftliche Kulturpflanzen, Gemüse, Obst und Sonderkulturen, Feldversuchswesen 7/1, Berlin.

Buxton D.R. (1996) Quality-related characteristics of forages as influenced by plant environment and agronomic factors, Anim. Feed Sci. Tech. 59, 37-49.

Chalk P.M. (1985) Estimation of $\mathrm{N}_{2}$ fixation by isotope dilution: An appraisal of techniques involving ${ }^{15} \mathrm{~N}$ enrichment and their application, Soil Biol. Biochem. 17, 389-410.

Cralle H.T., Heichel G.H. (1981) Nitrogen fixation and vegetative regrowth of alfalfa and birdsfoot trefoil after successive harvests or floral debudding, Plant Physiol. 67, 898-905.

De Kruijff R., Pietsch G., Freyer B., Friedel J.K. (2008) Pre-crop effects of alfalfa management systems on inorganic soil nitrogen and cereals in organic farming under pannonian site conditions, J. Plant Nutr. Soil Sci. 171, 576-579.

De Santis G., Iannucci A., Dantone D., Chiaravalle E. (2004) Changes during growth in the nutritive value of components of berseem clover (Trifolium alexandrinum L.) under different cutting treatments in a Mediterranean region, Grass Forage Sci. 59, 378-388.

Dierschke H. (1994) Pflanzensoziologie, UTB, Stuttgart-Hohenheim.

El-Hage Scialabba N., Hattam C. (2002) Organic agriculture, environment and food security, Environment and Natural Resources Series 4, FAO, Rome.

van Elsen T. (2000) Species diversity as a task for organic agriculture in Europe, Agr. Ecosyst. Environ. 77, 101-109.

Frame J., Charlton J.F.L., Laidlaw A.S. (1998) Lucerne (syn. Alfalfa), in: Frame J., Charlton J.F.L., Laidlaw A.S. (Eds.), Temperate forage legumes. CAB International, pp. 107-179.

Fried M., Middelboe V. (1977) Measurement of amount of nitrogen fixed by a legume crop, Plant Soil 47, 713-715.

Gossen B.D., Horton P.R., Wright S.B., Duncan C.H. (1994) Field responses of alfalfa to cut frequency, cultivar, crown pathogens and soil fertility. I. Survival and yield, Agron. J. 86, 82-88.

Hadatsch S., Kratochvil R., Vabitsch A., Freyer B. (2000) Potentials of Organic Farming in the Region of Marchfeld (Austria), in: Alföldi T., Lockeretz W., Niggli U. (Eds.), Proceedings of the 13th International IFOAM Scientific Conference. 28-31.8.2000, Convention Center Basel, p. 158.
Herridge D.F., Pate J.S. (1977) Utilization of net photosynthate for nitrogen fixation and protein production in an annual legume, Plant Physiol. 60, 759-764.

Hole D.G., Perkins A.J., Wilson J.D., Alexander I.H., Grice P.V., Evans A.D. (2005) Does organic farming benefit biodiversity? Biol. Conserv. 122, 113-130.

Kelemen J., Zuna-Kratky T., Weiß P., Teufelbauer N., Widler J., Schmidt J. (2003) Wirkungsgefüge Biolandbau und Artenschutz. Attraktivität von biologisch bewirtschafteten Feldern für Indikatorarten der offenen Agrarlandschaft im pannonischen Raum. Bericht an das Bundesministerium für Land- und Forstwirtschaft, Umwelt und Wasserwirtschaft, Distelverein, Deutsch-Wagram, pp. 52.

Kelemen-Finan J., Frühauf J. (2005) Einfluss des biologischen und konventionellen Landbaus sowie verschiedener Raumparameter auf bodenbrütende Vögel und Niederwild in der Ackerbaulandschaft: Problemanalyse - praktische Lösungsansätze, Synthese. Forschungsbericht im Auftrag des BMLFUW, Teilbericht 1.

Kim T.H., Ourry A., Boucaud J., Lemaire G. (1993) Partitioning of nitrogen derived from $\mathrm{N}_{2}$ fixation and reserves in nodulated Medicago sativa L. during regrowth, J. Exp. Bot., Vol. 44, 555-562.

Lamb J.F.S., Sheaffer C.C., Samac D.A. (2003) Population density and cut maturity effects on leaf and stem yield in alfalfa, Agron. J. 95, 635-641.

Latheef M.A., Caddel J.K., Berberet R.C., Stritzke J.F. (1988) Alfalfa forage yield, stand persistence, and weed colonization as influenced by variable first cut in Oklahoma, J. Prod. Agric. 1, 155-159.

Leach G.J. (1968) The growth of lucerne plant after cutting: the effects of cutting at different stages of maturity and at different intensities, Aust. J. Agr. Res. 19, 517-530.

Lemaire G., Khaity M., Onillon B., Allirand J.M., Chartier M., Gosse G. (1992) Dynamics of accumulation and partitioning of $\mathrm{N}$ in leaves, stems and roots of lucerne (Medicago sativa L.) in a dense copy, Ann. Bot.-London 70, 429-435.

Lloveras J., Ferran J., Alvarez A., Torres L. (1998) Cut management effects on alfalfa (Medicago sativa L.) production and quality in Mediterranean areas, Grass Forage Sci. 53, 88-92.

Loges R., Kaske A., Taube F. (1999) Dinitrogen fixation and residue nitrogen of different managed legumes and nitrogen uptake of subsequent winter wheat, in: Olesen J.E., Eltun R., Gooding M.J., Jensen E.S., Köpke U. (Eds.), Designing and testing crop rotations for organic farming. Proceeding from an international workshop. DARCOF Report 1/1999, pp. 181-190.

Martiniello P., Paoletti R., Berardo N. (1997) Effect of phonological stages on dry matter and quality components in lucerne, Eur. J. Agron. 6, 79-87.

Moder K. (1998) Comparison of some different statistical analyses to eliminate soil effects, Bodenkultur 49, 3-11.

Pate J.S., Herridge D.F. (1978) Partitioning and utilization of net photosynthate in nodulated annual legumes, J. Exp. Bot. 29, 401-412.

Petersen S., Axelsen J.A., Tybirk K., Aude E., Vestergaard P. (2006) Effects of organic farming on field boundary vegetation in Denmark, Agr. Ecosyst. Environ. 113, 302-306.

Pietsch G., Friedel J.K., Freyer B. (2007) Lucerne management in an organic farming system under dry site conditions, Field Crop. Res. $102,104-118$.

Pullen D.W.M., Cowell P.A. (1997) An evaluation of the performance of mechanical weeding mechanisms for use in high speed inter-row weeding of arable crops, J. Agr. Eng. Res. 67, 27-34. 
Putnam D., Russelle M., Orloff S., Kuhn J., Fitzhugh L., Godfrey L., Kiess A., Long R. (2001) Alfalfa, wildlife and the environment. California Alfalfa and Forage Association, http://www.calhay.org/ pdf/BrochureFINAL.pdf.

Reiter K., Schmidtke K., Rauber R. (2002) Estimation of symbiotic $\mathrm{N}_{2}$ fixation by a low-level, large-scale ${ }^{15} \mathrm{~N}$ application technique, Soil Biol. Biochem. 34, 303-314.

Sheaffer C.C., Martin N.P., Lamb J.F.S., Cuomo G.R., Jewett J.G., Quering S.R. (2000) Leaf and stem properties of alfalfa entries, Agron. J. 92, 733-739.

Stein-Bachinger K., Sperzel N., Petersen H. (2001) Naturschutzorientierte Nutzungsregime im ökologischen Feldfutterbau, Teil b: Landwirtschaftliche Aspekte, in: Reents H.J. (Ed.), Beiträge zur 6. Wissenschaftstagung zum Ökologischen Landbau 'Von Leit-Bildern zu Leit-Linien'. 6.-8.3.2001 FreisingWeihenstephan, pp. 151-154.

Stein-Bachinger K., Fuchs S. (2004) Wie kann der Lebensraum Acker im großflächigen Ökologischen Landbau für Feldvögel und Feldhase optimiert werden? Landbauforsch. Volk., FAL Agricultural Research, Special Issue 272, pp. 1-14.

Stein-Bachinger K., Zander P., Schobert H., Frielinghaus H. (2005) New ways of increasing biodiversity on organic farms and their effects on profitability: the nature conservation farm Brodowin, in: Köpke U., Niggli U., Neuhoff D., Cornish P., Lockeretz W., Willer, H. (Eds.), ISOFAR - Proceedings of the Conference 'Researching Sustainable Systems'. 21.-23.9.2005, Adelaide, pp. 468-471.
Stolze M., Piorr A., Häring A.M., Dabbert S. (2000) Environmental impacts of organic farming in Europe, Organic Farming in Europe: Economics and Policy, Vol. 6. University Stuttgart-Hohenheim.

Ta T.C., Faris M.A. (1987) Effects of alfalfa proportions and clipping frequencies on timothy-alfalfa mixtures. II. Nitrogen fixation and transfer, Agron. J. 79, 820-824.

Teixeira E.I., Moot D.J., Mickelbart M.V. (2007) Seasonal patterns of root $\mathrm{C}$ and $\mathrm{N}$ reserves of lucerne crops (Medicago sativa $\mathrm{L}$.) grown in a temperate climate were affected by defoliation regime, Eur. J. Agron. 26, 10-20.

Turner R., Lennartsson M.E.K., Bond W., Grundy A.C., Whitehouse D. (1999) Organic weed control - getting it right in time, in: Proceedings 1999 Brighton Conference - Weeds, Brighton, UK, pp. 969-974.

Veronesi F., Mariani A., Falcinelli M, Arcioni S. (1981) Adaptation of two lucerne populations to different cutting regimes, Agronomie 1, $733-738$

Volenec J.J. (1999) Physiological control of alfalfa growth and yield, in: Smith D.L., Hamel C. (Eds.), Crop Yield - Physiology and Processes, Springer-Verlag, Berlin-Heidelberg.

Wivstad M., Salomonsson L., Salomonsson A.C. (1996) Effects of green manure, organic fertilizers and urea on yield and grain quality of spring wheat, Acta Agric. Scand. 46, 169-177.

WRB (1998) World reference base for soil resources, FAO, Rome, p. 96. 